\title{
ПРОКУРОРСЬКИЙ НАГЛЯД, СУДОВИЙ І ВІДОМЧИЙ КОНТРОЛЬ ЗА ЗАСТОСУВАННЯМ ТЕХНІЧНИХ ЗАСОБІВ У КРИМІНАЛЬНОМУ ПРОВАДЖЕННІ
}

\author{
СЕМЕНЕНЕНКО Денис - аспірант кафедри кримінально-правових \\ дисциплін юридичного факультету Харківського національного університету \\ імені В. Н. Каразіна \\ УДК 343.16 \\ DOI 10.32782/LAW.2020.2.15
}

Установлень роль и место прокурорского надзора, судебного и ведомственного контроля в правовом механизме обеспечения охранъ прав и свобод личности в сфере применения технических средств в уголовном производстве. Сбормулированъ о оределения прокурорского надзора за применением технических средств в уголовном производстве, судебного контроля за применением технических средств в уголовном производстве и ведомственного контроля за применением технических средств в уголовном производстве. Определень основньие различия между обозначеннъими видами деятельности.

Формирование предложений по совершенствованию действующей нормативно-правовой базъи должно реализовъгваться на основании детального анализа действуюших норм законодательства по вопросам применения технических средств в уголовном производстве путем определения основнъих проблемнъих моментов, связаннъих c несовершенством положений как КПК Украинъг? так и других законов и подзаконньих актов.

Ключевые слова: технические средства, прочессуальньле гарантии, прокурорский надзор, судебный и ведомственньий контроль, следственнъие (розъскнъие) действия, негласньле следственнъие (розъискние) действия, уголовное

\section{Вступ}

Побудова правової держави передбачає наявність фундаментальної і стабільної системи законодавства, що забезпечує захист прав і законних інтересів особи одночасно з вирішенням завдань боротьби зі злочинністю.
При цьому є неприпустимим протиставлення інтересів суспільства й окремої особи. Порушення прав осіб не може бути виправдане мотивами державної необхідності. У цих умовах стає нагальним посилення захисту й охорони конституційних прав осіб [1, с. 2]

Огляд праць з даної проблематики

Проблематика охорони прав і свобод людини за допомогою прокурорського нагляду, судового і відомчого контролю постійно знаходиться в центрі уваги сучасних науковців. Зокрема, у своїх роботах до неї зверталися А.С. Жиліна, А.М. Кирій, І.Ф. Аітвінова, Г.П. Середа, Р.Р. Трагнюк, А.Р. Туманянц та інші дослідники. Однак у роботах зазначених авторів питання нагляду та контролю за застосуванням технічних засобів у кримінальному провадженні залишилися недостатньо висвітленими. Саме вирішальним значенням для практичної діяльності, а отже, і для забезпечення у державі режиму законності, в цілому обумовлене особливе місце вищезгаданих питань у юридичній науці [2, с. 61].

Сутність прокурорського нагляду, його місце в системі інших державно-правових інститутів, предмет та межі його реалізації до цього часу залишаються дискусійним питанням у науці та юридичній практиці [3, c. $7-26 ; 4$, c. $6-35]$.

Виклад основного матеріалу

Система прокуратури України створена на засадах спільності завдань, функцій, принципів ії організації діяльності, а також 
повноважень у частині виявлення правопорушень і засобів реагування на них. При цьому, до жодної з сучасних гілок державної влади прокуратура не входить. Основним іiі призначенням $\mathrm{e}$ виявлення порушень законодавства та вжиття заходів для їхнього усунення. При цьому - не важливо, у якій 3 галузей суспільного життя було виявлене порушення.

Визначеними функціями обумовлене особливе місце прокуратури в системі «стримок і противаг», що реалізуються в ході взаємовідносин між всіма гілками влади. Саме прокуратура виступає єдиним державним органом, для котрого нагляд за виконанням законів становить основу, сутність та зміст діяльності.

Так само, особливе місце посідає прокуратура у процедурах застосування технічних засобів у кримінальному провадженні, що обумовлено специфікою ії діяльності.

Загальні засади прокурорського нагляду, закріплені Конституцією України, знаходять свій розвиток у відповідних положеннях КПК України.

Разом з тим, стаття 107 КПК України, у якій викладені загальні засади застосування технічних засобів фіксування кримінального провадження, не містить прямих вказівок щодо особливостей прокурорського нагляду за застосуванням технічних засобів у кримінальному провадженні.

Так само стаття 252 КПК України, що містить положення про фіксацію ходу і результатів негласних слідчих (розшукових) дій, та якою передбачена можливість фіксації за допомогою технічних та інших засобів проведення негласних слідчих (розшукових) дій не містить прямих вказівок щодо особливостей прокурорського нагляду за застосуванням технічних засобів у кримінальному провадженні.

Враховуючи викладене, з метою визначення особливостей прокурорського нагляду за застосуванням технічних засобів у кримінальному провадженні, слід звернутися до загальних положень КПК України, якими врегульовані питання прокурорського нагляду за додержанням законів під час проведення досудового розслідування.

3 метою уточнення, які саме механізми прокурорського нагляду за застосуванням технічних засобів у кримінальному провадженні закріплені чинним КПК, існує необхідність додаткового аналізу положень чинного законодавства. Закон встановлює декілька форм діяльності прокурора із здійснення нагляду за застосуванням технічних засобів у кримінальному провадженні, основними 3 яких 6 :

- нагляд під час проведення процесуальної дії;

- нагляд при отриманні дозволу суду на проведення процесуальної дії;

- вирішення відповідних скарг на дії і рішення прокурорів та органів, що проводять досудове розслідування;

- розгляд повідомлень щодо порушення вимог чинного КПК України під час застосування технічних засобів.

Враховуючи викладене, а також положення частини 2 статті 36 КПК України, основні повноваження прокурора щодо нагляду за додержанням законів у ході застосування технічних засобів у кримінальному провадженні можуть бути сформовані наступним чином.

Прокурор, здійснюючи нагляд за додержанням законів у ході застосування технічних засобів у кримінальному провадженні, уповноважений:

- доручати слідчому, органу досудового розслідування проведення у встановлений прокурором строк слідчих (розшукових) дій, негласних слідчих (розшукових) дій, інших процесуальних дій із застосуванням технічних засобів, або давати вказівки щодо їх проведення чи брати участь у них, а в необхідних випадках - особисто проводити такі слідчі (розшукові) та процесуальні дії в порядку, визначеному КПК України;

- доручати проведення слідчих (розшукових) дій та негласних слідчих (розшукових) дій із застосуванням технічних засобів відповідним оперативним підрозділам;

- проводити перевірки законності застосування технічних засобів у кримінальному провадженні у порядку, визначеному законом;

- скасовувати незаконні та необгрунтовані постанови слідчих;

- ухвалювати процесуальні рішення у випадках, передбачених КПК України, у тому 


\section{Кримінальне право, кримінальний процес та криміналістика}

числі щодо закриття кримінального провадження та продовження строків досудового розслідування за наявності підстав, передбачених КПК України;

- погоджувати або відмовляти у погодженні клопотань слідчого до слідчого судді про проведення слідчих (розшукових) дій, негласних слідчих (розшукових) дій, інших процесуальних дій із застосуванням технічних засобів у випадках, передбачених КПК України, чи самостійно подавати слідчому судді такі клопотання;

- здійснювати інші повноваження, передбачені КПК України.

У сучасних наукових працях зазвичай використовується визначення прокурорського нагляду як регламентованої законодавчими i відомчими актами діяльності прокурора, направленої на виявлення та усунення порушень законності, захист конституційних прав і інтересів громадян, що виникає при здійсненні функцій прокурорського нагляду за додержанням і правильним застосуванням законів [5, с. 14].

Виходячи з загального визначення прокурорського нагляду, можливо сформувати відповідне визначення у сфері застосування технічних засобів: прокурорський нагляд за застосуванням технічних засобів у кримінальному провадженні - регламентована законодавчими і відомчими актами діяльність прокурора, направлена на виявлення та усунення порушень законності, захист конституційних прав і інтересів громадян у ході застосування технічних засобів, що виникає при здійсненні функцій прокурорського нагляду за додержанням і правильним застосуванням законів у кримінальному провадженні.

Досліджуючи питання судового контролю за застосуванням технічних засобів у кримінальному провадженні, слід зазначити, що судова влада виокремлюється такою формою діяльності як правосуддя, що передбачає розгляд і розв'язання на основі чинного законодавства економічних, політичних, управлінських та інших спорів, сторонами у яких можуть бути громадяни, їх об'єднання, юридичні особи, державні органи і органи місцевого самоврядування.

При цьому найголовнішою суспільною роллю судової влади в демократичному сус- пільстві є забезпечення панування права в ході розв'язання різноманітних юридичних конфліктів.

Здійснення судової влади покладено на відповідну систему судів. Кожен з них, незалежно від свого місця в судовій системі, від низового до верховного, вирішує конкретні справи самостійно, керуючись тільки законом і правосвідомістю, тобто є самостійним носієм судової влади. Цим судова влада принципово відрізняється від виконавчої, в системі, якої вищі органи керують нижчими i можуть давати вказівки щодо розв'язання питань, які входять до їх компетенції. Судова система не передбачає подібних відносин між їі складовими елементами.

На думку сучасних учених, судовий контроль здійснюється у трьох формах [5, с. 10].

1. Попередній, що полягає у розгляді i вирішенні подань про проведення процесуальних і оперативних дій, пов'язаних з обмеженням конституційних прав громадян.

2. Подальший у межах стадії досудового розслідування, коли судом розглядаються скарги на незаконні і необгрунтовані дії і рішення органу, що проводить досудове розслідування, слідчого і прокурора.

3. Подальший у судових стадіях процесу - це виявлення порушень, допущених при розслідуванні, у ході судового розгляду і на наступних стадіях процесу.

Як нами було встановлено у попередніх розділах даного дослідження, гарантії прав і свобод особи від необгрунтованого застосування технічних засобів у кримінальному провадженні включають у себе: гарантії права на життя; гарантії захисту честі і гідності; гарантії свободи та особистої недоторканості; гарантії недоторканості житла; гарантії таємниці листування, телефонних розмов, телеграфної та іншої кореспонденції; гарантії недоторканості особистого і сімейного життя.

У свою чергу, основні положення, які стосуються питань судового контролю за застосуванням технічних засобів у кримінальному провадженні (у тому числі - обов'язків судді щодо захисту прав людини, крім права на свободу та особисту недоторканість), містяться також у інших статтях КПК України. 
Зокрема, судовий контроль передбачений у ході розгляду і вирішення клопотань про проведення слідчих (розшукових) дій, пов'язаних 3 обмеженням конституційних прав громадян (статті 233 «Проникнення до житла чи іншого володіння особи»; 234 «Обшук» та інші), а також - негласних слідчих (розшукових) дій (глава 21 КПК України).

Враховуючи викладене, існує необхідність приведення назви статті 206 КПК України до іï фактичного змісту. 3 цією метою нами пропонується викласти назву вказаної статті у наступній редакції: «Стаття 206. Загальні обов’язки судді щодо захисту прав людини на свободу та особисту недоторканість».

Судовий контроль у кримінальному провадженні, на думку сучасних науковців, 6 діяльністю суду, направленою на перевірку законності і обгрунтованості дій і рішень посадових осіб, які здійснюють кримінальне провадження та повноти і всебічності розслідування справи, на підставі ініціативи суб'єктів кримінального процесу та осіб, інтересів яких торкається кримінальне провадження [5, с. 14].

Виходячи із визначення судового контролю у кримінальному провадженні, можливо сформувати відповідне визначення у сфеpi застосування технічних засобів: судовий контроль за застосуванням технічних засобів у кримінальному провадженні - діяльність суду направлена на перевірку законності і обгрунтованості дій і рішень посадових осіб, які застосовують технічні засоби у кримінальному провадженні на підставі ініціативи суб'єктів кримінального процесу та осіб, інтересів яких торкається кримінальне провадження.

До питання відомчого контролю за застосуванням технічних засобів у кримінальному провадженні слід зауважити, що науковий аналіз законодавчої бази, а також структурний аналіз організації окремих державних органів, що задіяні у цих процесах, уможливив дійти висновку про те, що контроль як одна 3 форм керуючого впливу керівників різних ланок і рівнів є однією з основних прерогатив керівників будь-якої управлінської ланки відповідних підрозділів і здійснюється або безпосередньо самим керівником того чи іншого підрозділу, або через конкретних підлеглих, призначених для виконання цих обов'язків, із наступною доповіддю керівникові.

Контроль за діяльністю підрозділів випливає із закріпленої законодавством загальної функції управління й оперативного керівництва з боку керівників, що очолюють органи, до складу яких входять зазначені підрозділи.

Таким чином, відомчий контроль за застосуванням технічних засобів у кримінальному провадженні, у першу чергу, здійснюється керівниками тих державних органів, що задіяні у відповідних процесах. Визначаючи нормативно-правовий статус цих органів, законодавець виділяє зазначену категорію посадових осіб, наділяючи їх повноваженнями по управлінню відповідними структурами. У свою чергу, така організація відомчого контролю дозволяе розробляти окремі відомчі документи, що містять методичні особливості організації та проведення заходів із застосуванням технічних засобів.

Безпосередніми суб'єктами відомчого контролю за застосуванням технічних засобів у кримінальному провадженні є також керівники відповідних підрозділів різного рівня, обсяг повноважень для яких визначається відповідними відомчими нормативними актами.

Проведене нами дослідження положень чинного КПК України свідчить, що на цей час існує ряд положень вказаного документу iз досліджуваного питання, які потребують наукового доопрацювання.

Таким чином, стаття 41 КПК України не містить положень щодо здійснення відомчого контролю за проведенням слідчих (розшукових) дій та негласних слідчих (розшукових) дій у кримінальному провадженні співробітниками оперативних підрозділів.

Разом 3 тим, дослідження основних положень чинного КПК України, пов'язаних iз застосуванням технічних засобів у кримінальному провадженні, свідчать про необхідність включення до КПК України відповідних положень.

Зокрема, більшість негласних слідчих (розшукових) дій, пов’язаних із втручанням у приватне спілкування із застосуванням технічних заходів, безпосередньо проводиться 


\section{Кримінальне право, кримінальний процес та криміналістика}

саме співробітниками оперативних підрозділів [6, с. 59; 7, с. 568], яким надане таке право у відповідності до статті 5 Закону України «Про оперативно-розшукову діяльність» [8].

Ми вважаємо, що відповідні положення щодо відомчого контролю слід закріпити у чинному КПК України та розширити їх дію по відношенню до гласних слідчих (розшукових) дій.

3 урахуванням викладеного, існує необхідність доповнення статті 41 КПК України частиною 4 наступного змісту: «4. Контроль за проведенням слідчих (розшукових) дій та негласних слідчих (розшукових) дій оперативними підрозділами здійснюється Міністерством внутрішніх справ України, Службою безпеки України, центральним органом виконавчої влади, що забезпечує формування та реалізує державну податкову і митну політику, центральним органом виконавчої влади, що реалізує державну політику у сфері виконання кримінальних покарань, спеціально уповноваженим центральним органом виконавчої влади у справах охорони державного кордону».

Сучасними науковцями процесуальний відомчий контроль визначено у якості діяльності начальника слідчого підрозділу та начальника органу, що проводить досудове розслідування, на підставі кримінального процесуального законодавства, нормативних та відомчих актів, яка направлена на розкриття кримінальних правопорушень, підвищення якості та скорочення строків провадження досудового розслідування, вжиття заходів щодо забезпечення відшкодування спричинених потерпілим збитків, забезпечення законності в діях підлеглих осіб [5, с. 10].

\section{Висновки}

Виходячи $з$ визначення процесуального відомчого контролю, можливо сформувати відповідне визначення у сфері застосування технічних засобів: відомчий контроль за застосуванням технічних засобів у кримінальному провадженні - це діяльність керівників відповідних підрозділів на підставі кримінального процесуального законодавства, нормативних та відомчих актів, яка направлена на забезпечення законності у ході застосування технічних засобів підлеглими особами.

Порівняльний аналіз прокурорського нагляду та суміжних напрямів діяльності уповноважених органів, таких як судовий та відомчий контроль у розрізі застосування технічних засобів у кримінальному провадженні свідчить про те, що, незважаючи на певні спільні ознаки (у першу чергу, йдеться про спільність завдань, що полягають у захисті прав людини у ході застосування технічних засобів), прокурорський нагляд і судовий контроль за законністю застосування технічних засобів у кримінальному провадженні мають суттєві відмінності. Зокрема, для системи прокуратури характерною є наявність чітких субординаційних відносин між іï складовими, у тому числі - у питаннях реалізації функцій прокурорського нагляду за законністю застосування технічних засобів у кримінальному провадженні.

Так само прокурорський нагляд і відомчий контроль за законністю застосування технічних засобів у кримінальному провадженні мають ряд суттєвих відмінностей. Зокрема, для суб'єктів здійснення прокурорського нагляду та відомчого контролю характерними є відмінності у визначених завданнях. Відомчий контроль є внутрішнім, у той час як прокурорський нагляд завжди зовнішній. Для прокурорського нагляду забезпечення ефективності застосування технічних засобів у кримінальному провадженні не $є$ метою, а виступає як побічний напрям діяльності.

\section{Аітература}

1. Літвінова I. Ф. Гарантії недоторканності житла чи іншого володіння особи у кримінальному процесі України: автореф. дис. ... канд. юрид. наук: спец. 12.00.09 «Кримінальний процес та криміналістика; судова експертиза; оперативно-розшукова діяльність» / І. Ф. Аітвінова. - К., 2010. - 22 с.

2. Тацій В. Прокуратура в системі поділу влади / В. Тацій, Ю. Грошевий // Вісник Академії правових наук України. - 1999. №1(16). - С.61-69..

3. Савицкий В. М. Очерк теории прокурорского надзора в уголовном судопроиз- 
водстве / В. М. Савицкий. - М. : Наука, 1975. -384 c.

4. Ломовский В. Д. Прокурорско-надзорные правоотношения / В. Д. Аомовский. - Ростов на Дону : Рост. гос. ун-тет, 1987. $196 \mathrm{c.}$

5. Кирій А. М. Відомчий, судовий контроль та прокурорський нагляд за відмовою в порушенні кримінальної справи: автореф. дис. ... канд. юрид. наук: спец. 12.00.09 «Кримінальний процес та криміналістика; судова експертиза» / А. М. Кирій. - К., 2007. $-17 \mathrm{c}$.

6. Шилін М. Оперативно-розшукова діяльність та негласні слідчі дії: проблеми правового регулювання у світлі нового Кримінального процесуального кодексу України / М. Шилін // Вісник Національної академії прокуратури України. - 2013. - №1. - С. 59-64.

7. Аевендаренко О. О. Негласні слідчі дії в контексті захисту конституційних прав i свобод учасників кримінального провадження / О. О. Аевендаренко, Д. В. Іващенко // Форум права. - 2012. - №4. - С. 567-571.

8. Про оперативно-розшукову діяльність: Закон України від 18 лютого 1992 р. № 2135XII// Відомості Верховної Ради України. 1992. - № 22. - С. 303 (зі змінами).

9. Жиліна $\mathcal{~}$. С. Прокурорський нагляд за додержанням законів при провадженні слідчих дій: автореф. дис. ... канд. юрид. наук: спец. 12.00.10 «Судоустрій; прокуратура та адвокатура» / А. С. Жиліна. - Харків, 1999. - 18 с.

10. Кирій А. М. Відомчий, судовий контроль та прокурорський нагляд за відмовою в порушенні кримінальної справи: автореф. дис. ... канд. юрид. наук: спец. 12.00.09 «Кримінальний процес та криміналістика; судова експертиза» / ^. М. Кирій. - К., 2007. $-17 \mathrm{c}$.

11. Трагнюк Р. Р. Прокурорський нагляд за додержанням законів, що забезпечують права обвинуваченого: автореф. дис. ... канд. юрид. наук: спец. 12.00.10 «Судоустрій; прокуратура та адвокатура» / Р. Р. Трагнюк. Харків, 2003. - 21 с.

12. Туманянц А. Р. Судовий контроль за законністю і обгрунтованістю процесуальних рішень органів досудового слідства: авто- реф. дис. ... канд. юрид. наук: спец. 12.00.09 «Кримінальний процес та криміналістика; судова експертиза» / А. Р. Туманянц. - Харків, 1998. - 16 c.

\section{References}

1. Litvinova I. F. Garantiï nedotorkannosti zhitla chi inshogo volodinnja osobi $u$ kriminal'nomu procesi Ukraïni: avtoref. dis. ... kand. jurid. nauk: spec. 12.00.09 «Kriminal'nij proces ta kriminalistika; sudova ekspertiza; operativno-rozshukova dijal'nist'» / I. F. Litvinova. - K., 2010. - 22 s.

2. Tacij V. Prokuratura v sistemi podilu vladi / V. Tacij, Ju. Groshevij // Visnik Akademiï pravovih nauk Ukraïni. - 1999. - №1(16). - S.61-69..

3. Savickij V. M. Ocherk teorii prokurorskogo nadzora v ugolovnom sudoproizvodstve /V. M. Savickij. - M. : Nauka, 1975. - 384 s.

4. Lomovskij V. D. Prokurorsko-nadzornye pravootnoshenija / V. D. Lomovskij. - Rostov na Donu : Rost. gos. un-tet, 1987. - 196 s.

5. Kirij L. M. Vidomchij, sudovij kontrol' ta prokurors'kij nagljad za vidmovoju v porushenni kriminal'noï spravi: avtoref. dis. ... kand. jurid. nauk: spec. 12.00.09 «Kriminal'nij proces ta kriminalistika; sudova ekspertiza» / L. M. Kirij. - K., 2007. - 17 s.

6. Shilin M. Operativno-rozshukova dijal'nist' ta neglasni slidchi diï: problemi pravovogo reguljuvannja u svitli novogo Kriminal'nogo procesual'nogo kodeksu Ukraïni / M. Shilin // Visnik Nacional'noï akademiï prokuraturi Ukraïni. - 2013. - №1. - S. 59-64.

7. Levendarenko O. O. Neglasni slidchi diï v konteksti zahistu konstitucijnih prav i svobod uchasnikiv kriminal'nogo provadzhennja / O. O. Levendarenko, D. V. Ivashhenko // Forum prava. - 2012. - №4. - S. 567-571.

8. Pro operativno-rozshukovu dijal'nist': Zakon Ukraïni vid 18 ljutogo 1992 r. № 2135-HII// Vidomosti Verhovnoï Radi Ukraïni. - 1992. № 22. - S. 303 (zi zminami).

9. Zhilina L. S. Prokurors'kij nagljad za doderzhannjam zakoniv pri provadzhenni slidchih dij: avtoref. dis. ... kand. jurid. nauk: spec. 12.00.10 «Sudoustrij; prokuratura ta advokatura» / L. S. Zhilina. - Harkiv, 1999. $18 \mathrm{~s}$.

10. Kirij L. M. Vidomchij, sudovij kontrol' ta prokurors'kij nagljad za vidmovoju v 


\section{Кримінальне право, кримінальний процес та криміналістика}

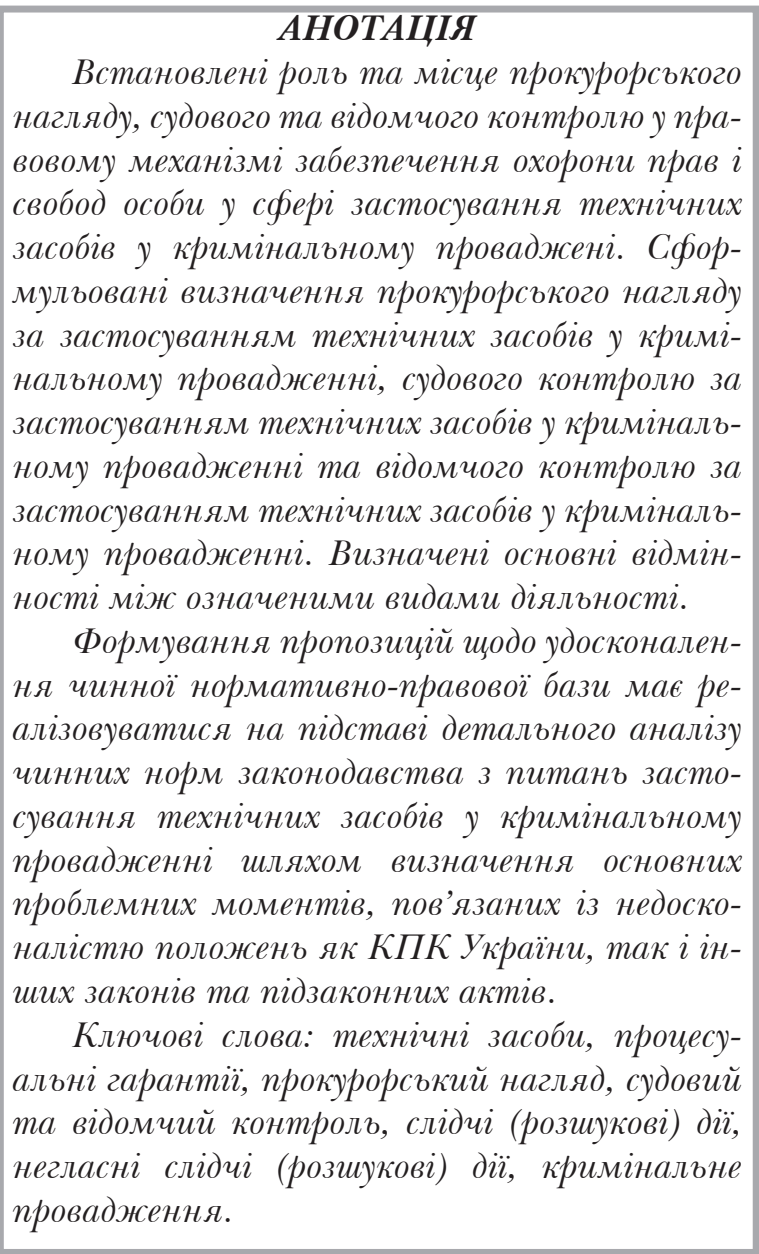

porushenni kriminal'noï spravi: avtoref. dis. ... kand. jurid. nauk: spec. 12.00.09 «Kriminal'nij proces ta kriminalistika; sudova ekspertiza» / L. M. Kirij. - K., 2007. - 17 s.

11. Tragnjuk R. R. Prokurors'kij nagljad za doderzhannjam zakoniv, shho zabezpechujut' prava obvinuvachenogo: avtoref. dis. ... kand. jurid. nauk: spec. 12.00.10 «Sudoustrij; prokuratura ta advokatura» / R. R. Tragnjuk. Harkiv, 2003. - $21 \mathrm{~s}$.

12. Tumanjanc A. R. Sudovij kontrol' za zakonnistju i obrruntovanistju procesual'nih rishen' organiv dosudovogo slidstva: avtoref. dis. ... kand. jurid. nauk: spec. 12.00.09 «Kriminal'nij proces ta kriminalistika; sudova ekspertiza» / A. R. Tumanjanc. - Harkiv, 1998. $-16 s$.
Links to bibliographic profiles / Посилання на бібліографічні профілі / Ссылки на библиографические профили:

https://scholar.google.com.ua/citations?h $\underline{l=\text { ru\&user }=\text { gqZUVtkAAAAJ \&scilu }=\& \text { scisi- }}$ $\mathrm{g}=$ AMD79ooAAAAAXWTFu61 fmmH82bXJi IPvVBBqZWsiZwJG\&gmla =AJsN-F4-8SN8x 9xklmB6KoOd8Dlo2cve7cn7qEWHFjNqYDPVNmpbTPTwszHwKjbzSQomMGKm9a0sTtA313wE90BbYilmrcL6A8kEs3A ksIgWHvfgJvYaHJ106Y4fAut79 P9Q eTO75PQ8Qa3Ehhznn tLLuUgKng\&sciund = 16637898719454209831 ;

https://orcid.org/0000-0001-8680-9692;

\section{Semenenenko Denis \\ PROSECUTOR'S SUPERVISION, JUDICIAL AND DEPARTMENTAL CONTROL OF THE USE OF TECHNICAL MEANS IN CRIMINAL PROGEEDINGS}

The role and place of prosecutorial supervision, judicial and departmental control in the legal mechanism for ensuring the protection of individual rights and freedoms in the field of using technical means in criminal proceedings have been established. The definitions of prosecutor's supervision over the use of technical means in criminal proceedings, judicial control over the use of technical means in criminal proceedings and departmental control over the use of technical means in criminal proceedings have been formulated. The main differences between the designated activities are identified.

Formulation of proposals to improve the current regulatory framework should be implemented on the basis of a detailed analysis of the current legislation on the use of technical means in criminal proceedings by identifying the main problem points associated with the imperfection of the provisions of the Criminal Procedure Code of Ukraine and other laws and regulations.

Key words: technical equipment, procedural guarantees, prosecutor's supervision, judicial and departmental control, investigative (search) actions, covert investigative (search) actions, criminal proceedings. 